\title{
"Una etapa siempre difícil": Concepts of Adolescence and Secondary Education in Mexico
}

\author{
BRADLEY A. LEVINSON
}

The concept of adolescence as a unique and difficult stage in the human life-course has itself followed a turbulent historical path. Although the term occasionally appeared in European texts from the medieval period, ${ }^{1}$ it was the U.S. psychologist G. Stanley Hall who in the late 1800s advanced the first "scientific" account of puberty's specific psychological entailments, which contributed to the more common and modern usage of "adolescence" we know today. Joseph Kett documents the influence of Hall's work at the turn of this century, and provides an intimate social history of the various groups in U.S. society that attempted to create institutions specifically attending to adolescent needs (i.e., Boy Scouts, the high school, etc.). ${ }^{2}$ In the United States and Europe, the concept of adolescence has since become thoroughly enmeshed in both popular and expert discourses on the behavior of youth, prompting Ariés to call this the "century" of adolescence. ${ }^{3}$ Academic journals and institutes, based primarily in departments of education and psychology, devote themselves entirely to the study of adolescence, while talk shows, books, and magazines communicate proverbial gems of wisdom to

EDITORIAL NOTE.-This article was accepted under the previous editorship.

Over the years, I have learned a great deal about the Mexican secundaria from Rafael Quiroz and Etelvina Sandoval. I have learned even more about the Mexican educational system from Elsie Rockwell, Ruth Mercado, Justa Ezpeleta, María de Ibarrola, María Bertely, Olac Fuentes, and Gabriela Delgado. I thank these fine scholars for their collegiality. I also thank those who gave the manuscript an especially close reading: Robert Arnove, Beatriz Calvo P., Erwin Epstein, and one anonymous reviewer. Others who provided useful feedback include Stephen Franz and Daniela Spenser. I would also like to thank the many helpful personnel in libraries and bookstores at the Instituto de Investigaciones Históricas (Universidad Michoacana, Morelia), El Colegio de Michoacán (Zamora), Departamento de Investigaciones Educativas (CINVESTAV-IPN, Mexico City), El Colegio de México (Mexico City), and the Universidad Pedagógica Nacional (Mexico City). My thanks finally to the National Academy of Education and the Spencer Foundation for a Postdoctoral Fellowship, which permitted me to complete this work.

${ }^{1}$ Philippe Ariés, Centuries of Childhood: A Social History of Family Life, trans. Robert Baldick (New York: Vintage, 1962), p. 25. Frank Musgrove, Youth and the Social Order (Bloomington: Indiana University Press, 1964), pp. 33-57, claims that Jean Jacques Rousseau originally "invented" the idea of adolescence in his 1762 educational treatise, Émile.

2 Joseph Kett, Rites of Passage: Adolescence in America 1790 to the Present (New York: Basic, 1977). See also Joseph Adelson, Inventing Adolescence: The Political Psychology of Everyday Schooling (New Brunswick, N.J.: Transaction, 1976); James Coleman, The Adolescent Society: The Social Life of the Teenager and Its Impact on Education (New York: Free Press, 1961); J. Demos and V. Demos, "Adolescence in Historical Perspective," Journal of Marriage and the Family 31 (1969): 623-39; Nancy Lesko, "Past, Present, and Future Conceptions of Adolescence," Educational Theory 46 (1996): 453-72; John Neubauer, The Fin-de-Siécle Culture of Adolescence (New Haven, Conn.: Yale University Press, 1992); and Merry White, The Material Child: Coming of Age in Japan and America (Berkeley and Los Angeles: University of California Press, 1993), pp. 29-35.

${ }^{3}$ Ariés, p. 32.

Comparative Education Review, vol. 43, no. 2.

(C) 1999 by the Comparative and International Education Society. All rights reserved. $0010-4086 / 99 / 4302-0001 \$ 02.00$ 
parents and teachers in search of advice about their charges. The prevailing thought characterizes adolescence as a universal psychological experience that, in evolutionary terms, we have only recently begun to understand and therefore socially and educationally accommodate. ${ }^{4}$ Meanwhile, a number of scholars have begun to question the value and relevance of such a concept. Like Ariés had previously done for the concept of childhood, these authors interrogate the analytical value of adolescence, wondering whether it represents, among other things, an ideological conflation of biological and sociocultural life stages central to the social control modalities of modern capitalist societies. ${ }^{5}$

Yet whatever their scientific or analytic value, the concept of adolescence has apparently found a welcome home among educational reformers in a number of countries. In the United States, the junior high school (grades 7-9) and high school (grades 10-12) have historically served as socializing institutions for early and middle adolescence, respectively. ${ }^{6}$ Secondary education programs in other countries have also addressed themselves to the putative needs of the adolescent life stage, and secondary curricula often reflect the subject content deemed appropriate for adolescent cognitive growth. Meanwhile, teacher training programs develop correspondingly apposite pedagogical strategies.

In Mexico, where I have conducted research since 1988, the concept of adolescence has always been a key point of reference in programs for the secundaria, a schooling cycle that corresponds to the U.S. junior high school, covering the postprimary period from grades 7-9. Periodic re-

${ }^{4}$ Even anthropologists, increasingly suspicious of universal behavioral constructs, have developed a framework for the cross-cultural study of adolescence. See Alice Schlegel and Herbert Barry, Adolescence: An Anthropological Inquiry (New York: Free Press, 1991). At least since Margaret Mead's controversial portrayal of carefree childhood and youth in Coming of Age in Samoa (New York: Morrow, 1928), debate has raged in anthropology about the cross-cultural recognition and experience of such a distinct life stage (James E. Coté, Adolescent Storm and Stress: An Evaluation of the Mead-Freeman Controversy [Hillsdale, N.J.: Erlbaum, 1994]). Little consensus appears to have emerged beyond a general acknowledgment that the biological transition to puberty, with its corresponding cognitive and affective changes, may be culturally constructed and socially channeled in myriad ways (S. Feldman and G. Elliott, eds., At the Threshold: The Developing Adolescent [Cambridge, Mass.: Harvard University Press, 1990]; H. Klein, "Adolescence, Youth and Young Adulthood: Rethinking Current Conceptualizations of Life Stage," Youth and Society 21 [1990]: 446-71; Ruby Takanishi and David A. Hamburg, eds., Preparing Adolescents for the Twenty-First Century [Cambridge: Cambridge University Press, 1997]; Christine Griffin, Representations of Youth: The Study of Youth and Adolescence in Britain and America [London: Polity, 1993]. As Erikson himself argued 30 years ago, most cultures have some kind of "institutionalized moratoria" between childhood and adulthood, but these vary greatly in type and duration (Erik H. Erikson, Identity: Youth and Crisis [New York: Norton, 1968]).

${ }^{5}$ For example, see David Bakan, "Adolescence in America: From Idea to Social Fact," in Rethinking Childhood, ed. Arlene Skolnick (Boston: Little \& Brown, 1976); Nancy Lesko, "Sujetos de la ciencia: El concepto de los adolescentes como el 'otro' en la investigación etnográfica," in Investigación etnográfica en educación, ed. Mario Rueda and Miguel Angel Campos (Mexico City: UNAM, 1992); Lesko, "Past, Present, and Future Conceptions of Adolescence"; Margaret J. Finders, Just Girls: Hidden Literacies and Life in Junior High (New York: Teachers College Press, 1997), pp. 121-22; Alison James and Allen Prout, eds., Constructing and Reconstructing Childhood: Contemporary Issues in the Sociological Study of Childhood (London: Falmer, 1990).

${ }^{6}$ Kett, pp. $236-41$. 
forms have often been articulated around the interrelated needs of adolescents and national development. The Mexican secundaria was created in 1923 , and it quickly evolved to accommodate prevailing concepts of adolescent life stage. The notion of adolescence may have been largely imported from the United States and Europe, but it was given unique meanings and functions in the Mexican context. Indeed, the historical and cross-cultural elaborations of the term prompt me to highlight its plurality and thus analyze concepts of adolescence.

For nearly 70 years, the secundaria served as an optional continuation of "basic" primary studies, and it developed a strong vocational component. For 50 of those years, the overwhelming majority of Mexican students sought only to complete 6 years of primary education. Typically, only those who envisioned a professional career continued beyond primary school, and they used the secundaria as a stepping-stone to further studies in urban areas, particularly at a college-linked preparatoria. ${ }^{7}$ By the 1970 s, however, secundaria enrollments had increased exponentially, and it was not uncommon to find students terminating their studies after completing this level. Among other things, the increased accessibility of these schools and a labor market grown accustomed to workers with secondary-level education contributed to the popularity of secondary studies. ${ }^{8}$

Still, it was not until 1993, in the context of broad administrative and curricular reforms, that the Mexican Constitution was amended to mandate compulsory secondary schooling. This was an unprecedented political move. Compulsory secondary education had long been the dream of some reformers, ${ }^{9}$ and by 1990 the Secretariat of Public Education (Secretaría de Educación Pública) had made great strides in providing communities with various options for secondary schooling..$^{10}$ Still, few thought the provision of secondary schooling could be extended to the entire population of school-age youth. Indeed, many primary schools were still overcrowded or, in some remote rural communities, nonexistent. Moreover, few resources could be dedicated to enforcing the compulsory rule, and after 10 years of economic

\footnotetext{
${ }^{7}$ The preparatoria, now considered an introductory component of higher education (educación media superior), typically offers a combination of general and specialized studies terminating in a specific bachillerato degree, which allows students to enter the corresponding career track at the university level.

8 Juan Prawda, Logros, inequidades y retos del futuro del sistema educativo mexicano (Mexico: Grijalbo, 1987); Annette Santos del Real, "La educación secundaria en México, 1923-1993" (Mexico City: Centro de Estudios Educativos, 1996), and "La secundaria: Modalidades y tendencias," in La educación secundaria: Cambios y perspectivas, ed. Instituto Estatal de Educación Pública de Oaxaca (IEEPO) (Oaxaca: Instituto Estatal de Educación Pública de Oaxaca, 1996), pp. 113-26.

${ }^{9}$ As early as 1937 , when the secundaria was still in its infancy, the great reformist President, Láaro Cárdenas, considered declaring it obligatory. See Ernesto Meneses Morales, Tendencias educativas oficiales en México, 1934-1964 (hereafter cited as 1934-1964) (Mexico City: Centro de Estudios Educativos, 1988), p. 122.

${ }^{10}$ In 1993, some 60 percent of secondary students were enrolled in "general" secundarias, 28 percent were enrolled in "technical" secundarias, and another 12 percent were enrolled in telesecundarias, a form of distance education offered to smaller rural communities. See Secretaría de Educación Pública (SEP), Educación básica secundaria: Plan y programas de estudio (Mexico City: SEP, 1993).
} 
crisis, many families were in no condition to support their children's ongoing studies. ${ }^{11}$ Most observers agreed that the constitutional amendment was primarily a symbolic measure, meant to signal Mexico's commitment to an advanced, "modern" education for the further economic development of the country. ${ }^{12}$ Ironically, the amendment coincided with the ongoing stagnation of teacher salaries and an increasingly combative movement for economic and political change in relations between teachers and the state. ${ }^{13}$ Many educational actors had become critical of the state's efforts at educational modernization, seeing in them a neoliberal program to dismantle the progressive social reforms of prior epochs. ${ }^{14}$

The development of the secundaria in Mexico and its link to shifting concepts of adolescence thus provide us with a unique window onto the educational trajectory of a globally circulating concept. Through its study, we can ascertain whether and how "local educational traditions are sufficiently entrenched" to alter and adapt globalizing secondary curricula. ${ }^{15}$ We can also assess how such curricula may change in response to successive waves of political economic reform, and how they are subject to new kinds of ideological configuration. Finally, we can approach the question of compulsory schooling through a single national case and examine its connection to developing conceptions of youth behavior and responsibility. ${ }^{16}$ In this article, I will show that in Mexico, as elsewhere, the growth of industrialization and the expansion of secondary education exerted reciprocal effects on one another and created the conditions for the salience of adolescence as a sociocultural category. ${ }^{17}$ However, the development of the secundaria and its related notions of adolescence also reflect an ongoing tension between Liberal traditions of

${ }^{11}$ In fact, from 1989-1992, the secundaria cycle experienced a net decrease in enrollments for the first time in many years. See Olac Molinar Fuentes, "La educación secundaria: Cambios y perspectivas" (versión estenográfica), in IEEPO, ed., p. 61.

12 The new "Plan and Program of Secondary Studies" published in 1993 suggested that "it has not been until recently that the development of the educational system has made it possible for nine years of schooling to be a genuine opportunity for the majority of the population and not just a goal consecrated by the law." Many would say, of course, that the "majority" now potentially served by the secundaria is still not as extensive as this document would have it. See SEP, Educación básica secundaria, p. 10.

${ }^{13}$ Joe Foweraker, Popular Mobilization in Mexico: The Teachers' Movement, 1977-87 (Cambridge: Cambridge University Press, 1993); María Lorena Cook, Organizing Dissent: Unions, the State, and the Democratic Teachers' Movement in Mexico (University Park, Pa.: Penn State Press, 1996); Susan Street, "Neoliberalism and Changing Conditions in Teachers' Work: Bottom-Up Responses in Jalisco, Michoacán, and Distrito Federal," paper presented at the annual meeting of the Comparative and International Education Society, March 19-23, 1997, Mexico City.

${ }^{14}$ For a perspective on this popular rejection of the neoliberal project through the resurgence of ideas from the regime of Mexican President Lázaro Cárdenas (1934-40), see Daniela Spenser and Bradley A. Levinson, "Linking State and Society in Discourse and Action: Political and Cultural Studies of the Cárdenas Era in Mexico," Latin American Research Review (in press).

${ }^{15}$ D. H. Kamens, J. W. Meyer, and A. Benavot, "Worldwide Patterns in Academic Secondary Education Curricula," Comparative Education Review 40 (1996): 116-38.

${ }^{16} \mathrm{John}$ Boli and Francisco Ramírez, "Compulsory Schooling in the Western Cultural Context," in Emergent Issues in Education: Comparative Perspectives, ed. R. F. Arnove, P. Altbach, and G. Kelly (Albany: State University of New York Press, 1992), pp. 25-38.

${ }^{17}$ Neubauer (n. 2 above), p. 6. 
individualism and the revolutionary tradition of nationalist collectivism in Mexico. The ambiguity wrought by this tension, persistent even through important political and ideological shifts, has placed its stamp on the way Mexicans attempt to educate adolescents.

My purpose in this article is to examine the historical and contemporary connections between the Mexican secundaria, the broader ideological and political-economic context of Mexican educational development, and concepts of adolescence in both expert discourse and popular culture. ${ }^{18}$ The social history of adolescence in Mexico has yet to be written, and my observations here are thus meant to be exploratory and suggestive. My approach is accordingly heterodox. I draw on multiple data, from original ethnographic observations to secondary historical sources and official documents, to paint a broad picture of the relation between adolescence and the secundaria. First, I present ethnographic evidence that in 1990, varied understandings of adolescence circulated at one provincial Mexican secundaria. Second, I examine educational philosophy in Mexico and present the major developments in the history of the secundaria as a discrete institution. I then return to the present moment to examine, once again, the multiple purposes and functions that have converged in the secundaria to "form adolescents." Finally, I analyze the latest program of studies promoted under the banner of educational modernization and suggest the intentions and effects it might have.

\section{An Ethnographic Introduction to Adolescence}

Since 1988, and for a full year from 1990-91, I have conducted fieldwork at a provincial secundaria in the west-central Mexican highlands. Located in a regional city of approximately 50,000 inhabitants, Escuela Secundaria Federal (ESF) serves a gamut of local social classes and groups, including some members of one of Mexico's most populous indigenous groups. ${ }^{19}$

From the outset of my research, I was struck by the ubiquity of the term "adolescence" (adolescencia). Teachers and parents wielded the phrase frequently to explain the behavior of their charges or to exhort students to follow a certain standard of conduct. It was not unusual to hear parents complain about their "adolescents" at meetings with teachers, or to hear teach-

\footnotetext{
${ }^{18}$ For an illuminating approach to the study of how "expert" theories become incorporated into popular, everyday cognitive schemes, see Charlotte Linde, "Explanatory Systems in Oral Life Stories," in Cultural Models in Language and Thought, ed. Dorothy Holland and Naomi Quinn (Cambridge: Cambridge University Press, 1987), pp. 343-66.

${ }^{19}$ For fuller descriptions of the research site and results, see Bradley A. Levinson, "Social Difference and Schooled Identity at a Mexican Secundaria," in The Cultural Production of the Educated Person: Critical Ethnographies of Schooling and Local Practice, ed. Bradley A. Levinson, Douglas E. Foley, and Dorothy C. Holland (Albany: State University of New York Press, 1996), pp. 211-38, "The Moral Construction of Student Rights: Discourse and Judgment among Mexican Secondary School Students," Journal of Contemporary Ethnography 27, no. 1 (1998): 45-84, as well as my forthcoming book, "We Are All Equal: Student Culture and Identity at a Mexican Secondary School and Beyond" (unpublished manuscript).
} 
ers respond with suggestions for firm discipline in the home. A parent at one meeting referred to what "the doctors" say about the hormonally driven caprice of adolescence, thus medicalizing the approach to childrearing. ${ }^{20}$ In another discussion, a parent expressed an oft-heard adult sentiment when she characterized adolescence as "una etapa siempre dificil" (always a difficult phase), because her daughter had become obsessively attuned to peer-based interaction and correspondingly truculent at home. During one of our discussions, the school's principal admitted that the school did not have sufficient resources (doctors, social workers, vocational counselors) to deal with the "special problems" of adolescents, even though the secundaria was specifically designed for such duty. Finally, teachers and parents alike frequently worried about adolescents' selfish impulses, wondering if they would continue to "pull" ( jalar), or cooperate, with the best interests of the family or school group. These characterizations of adolescencia highlight the problematic and contentious nature of the transition to adulthood as well as its emotional volatility and heightened sensitivity to generational difference. Such notions would probably be familiar to most U.S. or European parents and teachers. $^{21}$

Not all was storm and stress, however. Coexisting with this rather dire portrait of adolescence was a praiseful one. Teachers often portrayed the adolescent years as the happiest and most carefree the students were likely to encounter, and they often identified this period exclusively with the secundaria. In one classroom session toward the end of the year, a teacher told his group of soon-to-graduate students: "So I have seen how you all have changed, from childhood to adolescence, a very beautiful change . . . but kids, when you enter the preparatoria [high school level college preparatory] you're going to see that the secundaria was unique . . . because over there in the preparatoria things are very different; there's no longer the same conviviality (convivencia) in the group, and the students don't get to know each other as well." This was only one of many occasions where I witnessed a teacher prompting a kind of future nostalgia. Teachers repeatedly extolled the virtues of group solidarity and convivencia, and suggested that the adolescent years were relatively carefree. Adolescence was conceived as a safe and insulated training ground for adult roles and responsibilities. Kids could still feel free to be kids, to have fun with abandon, and to postpone the more serious decisions about life and career. According to teachers, for the 70 percent who would continue their formal studies, all this would end when they graduated from the secundaria. It was as if a summer of inevitable fate would suddenly transform these adolescents into "youth" (jóvenes).

Most striking of all was the way the students took up the terms of adoles-

${ }^{20}$ In Spanish this medical rhetoric is made even more resonant by the fact that the related verb, adolecer, means to "fall ill" or "suffer from" an affliction.

${ }^{21}$ Lesko, "Past, Present, and Future" (n. 2 above), p. 454; White (n. 2 above), p. 31. 
cence themselves. Familiar with U.S. adolescents' use of the term "kids" to describe themselves, I expected Mexican students to employ some homologue, reserving adolescente for adult use only. Yet they frequently used it as a label for themselves, as a way to explain or justify their own behavior. The greater contact and permeability between youth and adult cultures in Mexico, and the occasional adult use of adolescente as a term of address, ${ }^{22}$ clearly encouraged this appropriation. On one occasion, for instance, Leticia and her friends, obviously bored with recess, asked me what I would do if I were an "adolescent" at school that day. Not long after, I discovered another girl, my introspective friend Rosita, actually reading a book on "adolescents" when I stopped by her house to visit. She said she wanted to learn more from the "experts" about the emotional turmoil she was going through. Franco, a laconic boy with a remarkably sheepish grin, had once told me that the most important thing he had done in his short life was to serve as a Catholic altar boy and attend the priest's talks given especially for adolescentes. And students also equated adolescence with their years in the secundaria. For example, in a discussion taped toward the end of the school year, Ivan and Hector briefly suspended their jokester personas to confess that the transition they would soon make to the preparatoria was a momentous one:

Iván: In the prepa one moves on from being an adolescent to a youth [joven] who should be responsible in his way of being, his way of doing things for himself. One has to be more responsible in studying, and to be serious with the girls, not just to be thinking about nothing but sex, but to seriously conduct a nice friendship.

Héctor: Because in the prepa it's already about having a little more responsibility... the federal [ESF] is like a-how should I say it?-like a little review, something to teach yourself, but in the prepa it really depends on you.... Here [at ESF] one is still small and over there in the prepa one gets more savvy [agarra más mentalidad].

Frequently, students chatting with me would explain their laziness, indecision, or misconduct with reference to their "adolescent" nature. Clearly, they appropriated the term adolescente from parents, teachers, and the popular media and applied it to the understanding of their own educational experience.

This brief ethnographic presentation demonstrates the ongoing importance of concepts of adolescence for understanding and regulating the social life of youth in contemporary Mexico. It also hints at the active traffic in meanings between adult and youth uses of the term. The complexity of local articulations of adolescencia, and their association with the secundaria, have their roots in the Mexican educational philosophy and policy that have evolved over the course of this century. It is to these roots that I now turn.

\footnotetext{
${ }^{22}$ One of several examples I found in print, an article by a psychologist in a local newspaper, exhorts adolescentes to be decisive and productive: "Life is not for depending on others indefinitely. Education means passing from total dependence to full participation. . . . Mexico will be as productive as you are productive." Guillermo Ortíz González, "Adolescentes productivos," La voz de Michoacán (September 9, 1990).
} 
Citizenship or Human Capital? Critical Thinkers or Docile Workers? Dilemmas of Educational Philosophy and Policy in Mexico

Echoing the observations many contemporary educational scholars make of other nations, Carlos Ornelas describes the fundamentally "paradoxical" character of the Mexican educational system: its two primary mandates are to form "citizens" and "human capital." ${ }^{23}$ These mandates imply rather different kinds of educational priorities that have not been easily melded into a coherent educational policy. ${ }^{24}$ Annette Santos del Real and Yadira Navarro have noted, moreover, that the Mexican secundaria, adamantly opposed to academic tracking, still attempts to reconcile two related, but distinct goals: preparing youth for the immediate demands of the labor market and preparing youth for professional studies. ${ }^{25}$ Insofar as secondary education is thus conceived as both formative and vocational, both terminal and preparatory, it attempts to navigate a difficult middle course.

The dilemmas of Mexican education at its present level of development and differentiation are not unlike those encountered in many other parts of the world. Secondary structures and curricula around the globe attempt to address diverse educational goals. In former colonial nations, especially, the postprimary years are often used to accomplish work training and advanced academic preparation. What makes Mexico different? To answer this question, we must look beyond the stated goals of educational policy to more subtle configurations of value and ideology that sustain power relations in Mexican society. Only if we examine these more pervasive ideologies, and the associated distortions of dependent capitalist development, can we appreciate the uniquely Mexican ethos informing those dilemmas shared by other countries.

\footnotetext{
${ }^{23}$ Carlos Ornelas, El sistema educativo mexicano (Mexico City: SEP/Centro de Investigación y Docencia Económica, 1995), p. 49.

${ }^{24}$ Work by Noel McGinn and Susan Street, and Daniel A. Morales-Gómez and Carlos Alberto Torres, would suggest that even these two contradictory emphases are not really what drives policy formation. The political sociology of policy formation in Mexico during the 1970s and 1980s provides evidence that the building of "political capital" by educational bureaucrats, and the concern with state legitimation, really drive the development of educational policy. See Noel McGinn and Susan Street, "Has Mexican Education Generated Human or Political Capital?" Comparative Education 20 (1982): 323-38; Noel McGinn and Susan Street, "The Political Rationality of Resource Allocation in Mexican Public Education," Comparative Education Review 10 (1984): 178-98; Daniel A. Morales-Gómez and Carlos A. Torres, The State, Corporatist Politics, and Educational Policy-Making in Mexico, 1970-1988 (New York: Praeger, 1990).

${ }^{25}$ Santos del Real, La educación secundaria (n. 8 above), p. 1; Yadira Navarro, "La secundaria general," in IEEPO, ed. (n. 8 above), pp. 127-38. In a recent overview of educational initiatives in the state where ESF is located, a similar equivocation regarding the fundamental goals of the secundaria can be noted. First, the secundaria general is described as preparing students for further studies. The document suggests that only with the reforms of 1974 did the secundaria attempt to prepare students for both the workforce and further studies. Yet while a technical secundaria oriented more toward work training was introduced for the first time in 1959, it too was supposed to provide students the option of continuing their studies. José Reyes Rocha, ed., Acciones educativas en el Estado de Michoacán, 1980 - 86 (Morelia: Secretaría de Educación Pública, 1986), pp. 57-59. It is worth pointing out that nationally the "general" and "technical" secundarias are implicitly directed toward different constituencies: the general secundaria for the middle and upwardly mobile working classes preparing for further studies, the technical secundaria for the peasants and working classes pursuing a quicker entry into the workforce.
} 
I believe we can identify three distinct cultural formations in Mexico that have tugged and pulled at one another throughout the modern period. One I would call the "hierarchical holism" of the Mexican political body, traceable to the neo-Tomist Spanish state but represented perhaps best by the "Conservative" tradition of the early nineteenth century. Hierarchical holism describes a social system in which proper relations of authority, rooted ultimately in ecclesiastical and patriarchal imperatives, sustain the organic hierarchy of the "body" of God and his earthly appointments. While this formation typifies the Spanish colonial structure, it also draws from the hierarchical model of the largest indigenous pre-Hispanic polities. ${ }^{26}$ The other cultural formation would be the "Liberal" political tradition, with its principles of private property, individual initiative, rational progress, and formal equality before the law. The third, in effect a kind of uneasy synthesis of the other two, would be the tradition of revolutionary nationalism forged in the early part of this century, with its emphasis on collective solidarity and substantive equality. ${ }^{27}$ Revolutionary nationalism has itself undergone numerous challenges and permutations, and, as I hope to show, one place we can chart the evolving expression of revolutionary nationalism is in the structure and philosophy of the national education system.

As in so many other modern national contexts, notions of equality have suffused educational practice in Mexico. Yet the interpenetration of Mexico's cultural formations gives these notions a distinct cast. Mexico adapted from the Liberal tradition conceptions of equal opportunity, rationality, and mobility that accompanied the expansion of capitalist relations and the growth of anticlericalism. These conceptions dictate that schooling should free people from superstition and vice, giving them equal opportunities to improve their material lives and enter into the "productive" sphere of society. ${ }^{28}$ The Liberal model also designates schooling as a key instrument of meritocracy-a fair, equitable means of selecting the best people, on the basis of their aptitude, for the best positions within a technical division of labor. Citizens are "equal" in that they share basic qualities of humanity, such as the capacity for reflexive thought and moral action. Citizens are not, however, equal in the sense of having the "same" kind or level of aptitudes. As turn-of-the-century Liberal positivism would have it, they compete as

${ }^{26}$ Larissa Lomnitz, Claudio Lomnitz-Adler, and Ilya Adler, "The Function of the Form: Power Play and Ritual in the 1988 Mexican Presidential Campaign," in Constructing Culture and Power in Latin America, ed. Daniel Levine (Ann Arbor: University of Michigan Press, 1993), p. 369. See also Claudio Lomnitz-Adler, "Antropología de la nacionalidad mexicana," in Antropología breve de México, ed. Lourdes Arizpe (Mexico City: Academia de la Investigación Científica, 1993), pp. 343-71. Richard M. Morse was one of the first historians to underscore the hierarchical holism of the Spanish colonial tradition, using the term "patrimonialism." See Richard Morse, El espejo de Próspero: Dialéctica del Nuevo Mundo (Mexico City: Siglo XXI, 1982).

${ }^{27}$ Lomnitz et al. suggest that the postrevolutionary period has in fact been characterized by a "series of accommodations" between hierarchical holism and liberalism, but I prefer, at risk of reification, to call revolutionary nationalism a distinct, albeit hybrid, tradition.

${ }^{28}$ Mary Kay Vaughan, The State, Education, and Social Class in Mexico, 1880-1928 (Dekalb: Northern Illinois University Press, 1982). 
individuals within the same social space, on the same level playing field, allowing the "natural" hierarchy of ability to best serve the social interest. ${ }^{29}$

Since the Mexican Revolution, the Mexican state has appropriated components of this Liberal discourse of equality to articulate its own brand of revolutionary nationalism. The state represents itself as an active agent in social leveling, demolishing the artificially hierarchical and unjust structures that had governed pre-revolutionary Mexico. Notions of equality thus serve to encourage "misrecognition" of structural inequalities that either continue or emerge after the revolutionary period. ${ }^{30}$ In postrevolutionary Mexico, ironically, equality of groups (unions, collective farms, political parties, neighborhood associations, etc.), as well as individuals, defines the national community. Despite particular allegiances and identities, persons and the groups they form are all "equal"- that is, in a certain sense, the "same"-as Mexicans. Unlike the Australian egalitarian nationalism discussed by Bruce Kapferer, in which the individual represents the "fundamental unit of value," ${ }^{31}$ Mexican revolutionary nationalism develops the corporatist model to construct communities (based on occupation, class, ethnicity, or locality) loyal to the state..$^{32}$ Moreover, unlike Australian nationalism, which posits a sharp distinction between the state apparatus and the culturally defined nation, Mexican nationalism, through cultural processes of postrevolutionary regime legitimation, has come to be identified with the state itself. ${ }^{33}$ The state thus attempts to construct an inclusive Mexicanness that draws on Liberal principles of equality as well as a quasi-colonial hierarchical holism - a corporate structure in which group membership stipulates a proper position in the social order as "equal" subjects of the state.

${ }^{29}$ Charles Hale, in two separate books, has authored perhaps the definitive account of Mexican liberalism in the nineteenth century. He emphasizes the particularities of the Mexican case, especially the rise of scientific positivism and the avoidance of the "Indian" question, which was not fully addressed until after the Revolution. See Charles A. Hale, El liberalismo mexicano en la epoca de Mora, 1821-1853 (1968; reprint, Mexico City: Siglo XXI, 1971), and The Transformation of Liberalism in Late Nineteenth Century Mexico (Princeton, N.J.: Princeton University Press, 1989).

${ }^{30}$ I have appropriated and extended the term "misrecognition" from Pierre Bourdieu's original work on symbolic capital, Outline of a Theory of Practice (Cambridge: Cambridge University Press, 1977), pp. 171-83. Erwin Epstein has argued even more forcefully that the Mexican focus on national identity and unity in education specifically attempts to counteract the sense of degradation and dispossession produced by extreme social inequalities. Since an awareness of large socioeconomic disparities is likely to render national identity more fragile, public education is committed, at least discursively, to promoting equality. This equality is linked with the goals of civic participation and national solidarity. Epstein's observations fit well with my own argument, for it is in this sense that the discursive formation of national identity attempts to produce a mediation, even a misrecognition, of the actually existing, material structures of inequality. See Erwin Epstein, "National Consciousness and Education in Mexico," in Education in Latin America, ed. C. Brock and H. Lawlor (London: Croom Helm, 1985).

${ }^{31}$ Bruce Kapferer, Legends of People, Myths of State: Violence, Intolerance, and Political Culture in Sri Lanka and Australia (Washington, D.C.: Smithsonian Institution Press, 1988), p. 14.

32 Phillipe C. Schmitter, "Still the Century of Corporatism?" in The New Corporatism: Social-Political Structures in the Iberian World, ed. F. B. Pike and T. Strich (South Bend, Ind.: University of Notre Dame Press, 1974), pp. 85-131; Viviane Brachet-Márquez, The Dynamics of Domination: State, Class, and Social Reform in Mexico, 1910-1990 (Pittsburgh: University of Pittsburgh Press, 1994).

${ }^{33}$ Gilbert M. Joseph and Daniel Nugent, eds., Everyday Forms of State Formation: Revolution and the Negotiation of Rule in Modern Mexico (Durham, N.C.: Duke University Press, 1994). 
The rationalist, meritocratic model of education had become predominant by the end of the last century, when the Liberal hegemony in Mexico had been consolidated. It was not until after 1910, with the explosion of social revolution in Mexico, that new forms of educational ideology and practice were grafted onto the Liberal base. A renewed emphasis on cooperation, solidarity, and the collective good, oriented toward the construction of a national identity and national culture, took its place alongside the Liberal model of individualism. ${ }^{34}$ The collectivist emphasis, coupled with the corporatist political structure, drew on already existing practices and discourses of solidarity in popular and indigenous cultures, articulating their local, community-oriented focus to a hegemonic national project. ${ }^{35}$ This unique configuration helps explain why Mexico remains at least partially refractory to the cultural rationalization of the modern West, which John Boli and Francisco Ramírez claim is key to the expansion of Western-style compulsory schooling. ${ }^{36}$ Although Mexico's Liberal constitution of 1857 made primary schooling "obligatory," such schooling was effectively extended beyond Mexico City's middle and upper classes only after the Revolution, in 1921.

Why is the secundaria important in this framework of state and nation formation? In modernizing and urbanizing Mexico, as elsewhere, the transitional stage known as adolescence has become a crucible for forging enduring identities and allegiances, and the secundaria corresponds to this stage. Children and youth now form an extremely high percentage of Mexico's population, ${ }^{37}$ and educational authorities must clearly design a secundaria that accommodates and channels youth for productive places in society. Moreover, one of the main points that typically distinguishes the secundaria from the primaria is its generally greater mixing of social classes and ethnicities. ${ }^{38}$ Except perhaps in the largest cities and centers of intense migration, ${ }^{39}$ primary schools are more homogeneous in class and ethnic terms because they tend to serve more uniform neighborhoods and communities. Thus, the nationalist ideology of equality as "sameness" is likely to be expressed more urgently in the secundaria, where the social differences that the ideology attempts to integrate are more salient and deeply rooted. Indeed, at least since 1944, the secundaria appears to have been explicitly invested with this homogenizing function..$^{40}$ Finally, the secundaria seems to

\footnotetext{
${ }^{34}$ Mary Kay Vaughan, Cultural Politics in Revolution: Teachers, Peasants, and Schools in Mexico, 19301940 (Tucson: University of Arizona Press, 1997).

${ }^{35}$ Claudio Lomnitz-Adler, Exits from the Labyrinth: Culture and Ideology in the Mexican National Space (Berkeley and Los Angeles: University of California Press, 1992); Ana María Alonso, Thread of Blood: Colonialism, Revolution, and Gender on Mexico's Northern Frontier (Tucson: University of Arizona Press, 1995).

${ }^{36}$ Boli and Ramírez (n. 16 above).

${ }^{37}$ In 1993, some 18 million children were enrolled in primary and secondary schools alone-more than 20 percent of Mexico's total estimated population of 85 million.

${ }^{38}$ Secundarias in larger urban centers and smaller towns may tend toward greater homogeneity, but always less than the primarias that feed into them.

${ }^{39}$ Beatriz Calvo Pontón, personal communication, 1997.

${ }^{40}$ Santos del Real, La educación secundaria (n. 8 above), p. 8.
} 
have crystallized in the very structure and rationale of its curriculum the tension between Liberal individualism and nationalist collectivism, between effort for personal advancement and technical mastery, on the one hand, and effort for group welfare and solidary citizenship, on the other. In order to appreciate the relation between this curriculum and concepts of adolescence, we must situate the historical development of the Mexican secundaria in the context of the "basic education" cycle in Mexico.

\section{Historical Contextualization of the Mexican Secundaria}

While there were some early attempts at creating public schools after Independence (1821), it was not until the Liberal reform period of the late nineteenth century that public schooling received serious attention as a potential tool for national development. ${ }^{41}$ At this time the discursive foundations of egalitarian individualism came to be articulated, particularly in the thought of Gabino Barreda. For Barreda, all Mexicans, regardless of social class, required and deserved the moral and technical benefits of universal schooling. These benefits would also redound to the national good, as the general moral and productive level of society improved.

Despite the implicitly egalitarian premises of Barreda's liberal positivism, throughout the period of the Porfirio Díaz dictatorship (1876-1910) leading up to the Mexican Revolution, public schooling was extended primarily to the urban middle classes. Arguing against the social Darwinists and others who rejected public education as an equalizing force, Justo Sierra and the positivists in charge of the Secretariat of Public Instruction advocated universal obligatory schooling but could not garner the material resources to realize their vision. It would take the explosion of popular demands ignited by the Revolution to prompt the postrevolutionary state to begin forging a truly mass-based school system with nationalist pretensions. Yet many of the conceptual foundations for such a project were already in place. ${ }^{42}$

The federal state emerging from the Revolution ultimately reinstated the hegemony of a corporate capitalism initially fostered by the Díaz regime, but it did so under radically changed social and ideological conditions. ${ }^{43}$ Now more than ever it was necessary for the state to attend to the great range of class, ethnic, and regional differences that divided the nation, and school-

${ }^{41}$ Josefina Vázquez de Knauth, Nacionalismo y educación en México (Mexico City: El Colegio de México, 1970); Martha Robles, Educación y sociedad en la historia de México (Mexico City: Siglo XXI, 1977); Vaughan, The State, Education, and Social Class (n. 28 above); María Teresa Bermúdez, "Vueltas y revueltas en la educación, 1860-1876," in Ideas, valores y tradiciones: Ensayos sobre historia de la educación en México, ed. Mílada Bazant (Toluca: El Colegio Mexiquense, 1996), pp. 111-28.

${ }^{42}$ Bartra notes that "the modern conception of the Mexican spirit, the 'new man' that the Revolution required, does not arise in a sudden outburst of nationalism. In fact, many of the features of the Mexican character are described, exalted, and criticized by the positivist liberal intellectuals of the beginning of the twentieth century." See Roger Bartra, The Cage of Melancholy: Identity and Metamorphosis in the Mexican Character, trans. Christopher J. Hall (New Brunswick, N.J.: Rutgers University Press, 1992), p. 5.

${ }^{43}$ Brachet-Marquez (n. 32 above); Joseph and Nugent, eds. (n. 33 above); Vaughan, Cultural Politics in Revolution. 
ing was an obvious choice for accomplishing this feat of national integration. With the Revolution, the first material bases for a genuinely popular public schooling were established, and the question of equality and social difference moved to the forefront.

Still, there was no simple correspondence between popular demands and the educational programs the state would eventually propose. Indeed, postrevolutionary educational developments embodied the contradictions of a modernizing, capitalist state trapped by the rhetoric and commitments wrought by revolution. The state's solution attempted to balance the heterogeneity of popular demands with the need for strong, centralized control. Community demands had to be articulated forcefully and resourcefully for local actors to retain some control over the kinds of education they sought. There was a constant, and not always pacific, negotiation of popular demands, or "rights," ${ }^{44}$ as the state sought to define its relationship to various communities and constituencies. ${ }^{45}$ Such negotiation often brought out ancient rifts and antagonisms in local communities, most notoriously between devout Catholics and those more inclined toward a radical agrarianism. ${ }^{46}$

What were some of the key features of education in the postrevolutionary period? Olac Fuentes has called attention to the important development of administrative centralization, which emerged as an alternative to decentralized, community control:

In 1921, when the energetic group that triumphed in the Revolution assigned to the new state the task of national and popular education, [they] abandoned the liberal notion, favored by Carranza, of an educational apparatus not centrally controlled, but distributed between local forces and open to the action of private agencies. Instead, they adopted the model of a strong and expansive state, able to penetrate into every corner of social life, interested in promoting a new kind of lay morality that would associate the past and the future, integrate social classes, and dissolve their conflicts in the shared values of progress and national destiny. ${ }^{47}$

${ }^{44}$ Mercado, in her fine ethnography of a rural primaria, argues that one of the key ways the postrevolutionary state constitutes and legitimates itself is by transforming the popular claims and demands of the Revolution into rights. See Ruth Mercado, "La educación primaria gratuita: Una lucha popular cotidiana," Cuadernos de investigación, no. 17 (Mexico City: Departamento de Investigaciones Educativas, 1985).

${ }^{45}$ Elsie Rockwell, "Schools of the Revolution: Enacting and Contesting State Forms in Tlaxcala (1910-1930)," in Joseph and Nugent, eds., pp. 170-208; Elsie Rockwell, "Keys to Appropriation: Rural Schooling in Mexico," in Levinson et al., eds. (n. 19 above), pp. 301-24. See Florencia Mallon's Peasant and Nation: The Making of Postcolonial Mexico and Peru (Berkeley and Los Angeles: University of California Press, 1995) for a remarkable demonstration of how such complex negotiations of rights and demands have their origins in mid-nineteenth-century political-military struggles.

${ }^{46}$ Majorie Becker, Setting the Virgin on Fire: Lázaro Cárdenas, Michoacán Peasants, and the Redemption of the Mexican Revolution (Berkeley and Los Angeles: University of California Press, 1995); Adrian A. Bantjes, "Burning Saints, Molding Minds: Iconoclasm, Civic Ritual, and the Failed Cultural Revolution," in Rituals of Rule, Rituals of Resistance: Public Celebrations and Popular Culture in Mexico, ed. William H. Beezley, Cheryl English Martin, and William E. French (Wilmington, Del.: Scholarly Resources, 1994); Vaughan, Cultural Politics in Revolution (n. 34 above); Susana Quintanilla and Mary Kay Vaughan, eds., La educación socialista en el contexto regional (Mexico City: Fondo de Cultura Económica, 1997).

${ }^{47}$ My translation. Olac Molinar Fuentes, Educación y politica en México (Mexico City: Nueva Imagen, 1983), p. 26. 
Significantly, Fuentes observes the link between this model of educational centralization and the goal of a nation-oriented equality. Only through the agency of a "strong and expansive state" could Mexican educators hope to overcome sharp social divisions and forge a modern nation, especially important in the face of the ever present threat posed by their powerful U.S. neighbor to the north. ${ }^{48}$ This strong state also found itself nourished by the persistent ideological power of hierarchical holism, which fed the habits of centralized authority.

In 1921, soon after the definitive triumph of the Revolution, President Alvaro Obregón appointed José Vasconcelos to serve as founding head of a new federal Secretariat of Public Education. Vasconcelos followed Barreda in elaborating the nationalist justification for an aggressive federalization of popular education. He articulated a vision of revolutionary cultural action that, for perhaps the first time in the country's independence, explicitly valorized the contributions of "popular" and "indigenous" culture. Yet, perhaps paradoxically, he also laid the groundwork for a system of schooling that would be oriented toward homogenizing the customs and values of all Mexicans in the service of two predominant statist imperatives: national unity, and the material and spiritual redemption, or "elevation," of popular classes. $^{49}$

The development of federal schooling, especially in rural areas, would succeed because it responded to a number of popular demands. The idea of rural schools as casas del pueblo (houses of the people), first conceived by Vasconcelos and then developed by the great educator Moises Sáenz, was received enthusiastically in many villages. The model of the rural school had been influenced by the active, participatory pedagogy of John Dewey, with whom Sáenz had studied at Columbia University. Rural schoolteachers were much more than instructors of literacy and mathematics. Rather, teachers were conceived as moral, social, and technical "apostles" of modernity, guiding their communities to practical and spiritual liberation - and integration

${ }^{48}$ González Chávez documents the displacement of widespread and popular "local education committees"- which linked the interests of municipalities and state governments-by the development of centralized federal education after the Revolution. See Humberto González Chávez, "La educación, el municipio, y el estado," in El municipio en México, ed. Brigitte Boehm de Lameiras (Zamora: El Colegio de Michoacán, 1987), pp. 585-600; Humberto González Chávez, "The Centralization of Education in Mexico: Subordination and Autonomy," in State and Society: The Emergence and Development of Social Hierarchy and Political Centralization, ed. John Gledhill, Barbara Bender, and Mogens Trolle Larsen (London: Unwin Hyman, 1988).

${ }^{49}$ Eva Taboada, "Educación y lucha ideológica en el México posrevolucionario," in Educación y clases populares en América Latina, ed. María de Ibarrola and Elsie Rockwell (Mexico City: Departamento de Investigaciones Educativas, 1985), pp. 45-46. Hale argues that the themes of Vasconcelista thought were importantly prefigured by Liberal "scientific positivists" like Barreda and Sierra (The Transformation of Liberalism [n. 29 above], pp. 223-34). Compare Vaughan, The State, Education, and Social Class. Carlos Newland situates this Mexican development in the context of Latin America at that time, where the "liberal hegemony" gave to nation-states the charge of centralizing education for the goal of "homogenizing" a diverse population. See Carlos Newland, "The Estado Docente and Its Expansion: Spanish American Elementary Education, 1900-1950," Journal of Latin American Studies 26 (1994): 449-67. 
into national life. ${ }^{50}$ In addition to the schools themselves, "cultural missions" were created at strategic locations in rural parts of the country. The missions were intended to serve as resource centers for teachers and other interested citizens, who could consult both materials and master pedagogues in order to more effectively teach villagers the latest skills. The intense cultural action of the revolutionary state was thus double-edged. While education responded to rural needs and demands, it also deepened the power of state rule..$^{51}$

Many authors have thus called attention to the manner in which postrevolutionary schools were charged with creating, or in some cases reinforcing, a unified national identity. ${ }^{52}$ The regional and local identifications which had inspired diverse revolutionary movements constantly threatened the integrity of the postrevolutionary state. In effect, the penetration of statesponsored schooling into previously neglected local communities represented an attempt to link these communities to the state and thus consolidate the hegemonic rule of revolutionary elites. ${ }^{53}$ The popular regime of Lázaro Cárdenas (1934-40), who established a controversial program of "socialist education," nevertheless culminated this process of state formation. ${ }^{54}$ What occurred during this period was also an attempt to identify the nation in cultural terms with the groups comprising the state. ${ }^{55}$ The nationalist concept of equality as a collective good became the ideological ground for a smooth consolidation of hegemonic rule and, especially after 1940, capitalist development. Such a concept was especially highlighted during the so-called period of national unity (post-1940), which followed the contentious era of socialist agitation. Even the language of the constitutional article specifying the goals of the educational system, revised in 1946 (see below), sketched the relationship between equality and national identity:

[Education] should tend to create and affirm in students concepts and feelings of solidarity and the preeminence of collective interests over private or individual

${ }^{50}$ Vaughan, Cultural Politics in Revolution.

${ }^{51}$ Elsie Rockwell's work on primary schools in a rural region of Mexico brilliantly demonstrates the interplay of local and national interests, and shows how the teaching experience was often transformative for local educators themselves. See Rockwell, "Schools of the Revolution" and "Keys to Appropriation."

${ }^{52}$ See, e.g., David Raby, "Ideología y construcción del estado: La función política de la educación rural en México, 1921-35," Revista mexicana de sociología 2 (1987): 305-20; Taboada; Vaughan, Cultural Politics in Revolution.

${ }^{53}$ Raby, "Ideología,” p. 308; Arnaldo Córdova, “El populismo en la educación nacional, 19201940," in Ideología educativa de la Revolución mexicana, ed. Graciela Lechuga (Mexico City: Universidad Autónoma Metropolitana, 1984); Taboada, p. 54.

${ }^{54}$ There is still a vigorous historical debate about the meanings and intentions of the Cárdenas regime, which oversaw the construction of an inclusive corporatist structure that has persisted to the present day. Many claim that Cárdenas fulfilled popular democratic aspirations of the Revolution and that his populism served to empower previously fractured and disenfranchised groups. Others interpret the corporatist scheme as a more effective mechanism for securing consent and legitimating the ongoing rule of a privileged elite. See Alan Knight, "Cardenismo: Juggernaut or Jalopy?" Journal of Latin American Studies 26 (1994): 73-107; Spenser and Levinson (n. 14 above).

${ }^{55}$ Carlos Monsiváis, "Muerte y resurreción del nacionalismo mexicano," in El Nacionalismo Mexicano, ed. Cecilia Noriega Elio (Zamora: El Colegio de Michoacán, 1992), p. 448. 
interests, with the goal of lessening social and economic inequalities. ... Through instruction and school activities, [education] will contribute to the development and consolidation of national unity, thereby excluding all political, social, and sectarian influences contrary or inimical to the country, and affirming in students the love of country ( patria) and national traditions. ... Special attention will be given to the study of the country's economy, environment, and social conditions in order to achieve the most equitable use of its natural resources. ${ }^{56}$

Indeed, if a "new Mexican" was created in revolutionary discourses on equality, it was a cultural subject oriented toward the collective (read national) good. ${ }^{57}$

The Secundaria, the Adolescent, and the Nation, 1923-93

How do the secundaria and emerging concepts of adolescence fit into this pattern of state-society relations? In this section, I examine the development of policy and curriculum for the secundaria proper, exploring the tensions and shifts between individualistic and collectivistic prescriptions for adolescent education, and between training for work and preparation for advanced studies. I thereby note how global trends in secondary education uniquely evolved in the Mexican context.

Although the public secundaria was officially created by law in 1915, it was not until 1923, shortly after the first rural primarias were brought into being, that the secundaria received serious attention. Until that time, Mexico had followed the classical European tradition of combining secondary education with college preparatory studies. Secondary education was in effect part of a program of professional studies that emphasized specialization and encyclopedic knowledge. In 1923, Bernardo Gastélum, subsecretary of education, proposed a reorganization of college preparatory studies by clearly distinguishing a phase of secondary education as an extension of the primary school. In this manner, the secundaria would retain some of the subject matter and specialization characteristic of preparatory studies but would also continue the "basic" cultural and ideological functions of the primaria. Following the Liberal imperative to wrest power from the Church and assign the task of moral socialization to the state, the secundaria would now focus on the formative education of the character rather than the instruction of specialized knowledge. ${ }^{58}$

\footnotetext{
${ }^{56}$ This is my translation of sections from p. 129 of the Ley Orgánica de la Educación Pública from 1941, as reproduced in Margarita Campos de García, Escuela y comunidad en Tepetlaoxtoc (Mexico City: Sepsetentas, 1973), pp. 42-43. This law is an elaboration of the Third Constitutional Article of 1917, which stipulates that education in Mexico will be secular, gratis, and compulsory through primary school. The 1917 Constitution, which was hammered out even before revolutionary hostilities had ceased, and which remains the operative national law in Mexico, retained much of the original Liberal Constitution of 1857.

${ }^{57}$ Bartra (n. 42 above).

${ }^{58}$ The debate over "education" versus "instruction" apparently dates from the late nineteenth century (Hale, The Transformation of Liberalism, p. 162). In Spanish, "educación" implies a broad formation of character, manners, and morals, while "instrucción" implies the transmission of specialized knowledge. The Church, along with the family, had traditionally held a monopoly over the "education" of children. Liberals at the end of the century argued among themselves over whether the displacement of Church
} 
Donald Mabry suggests that the idea of the secundaria was borrowed from the United States, and thus fiercely resisted by traditionalists who wished to preserve a strict separation between primary and advanced education and who feared the incursion of "foreign" educational philosophies. ${ }^{59}$ Raúl Mejía goes further in saying that the Secretariat of Public Education founded the secundaria with the "pedagogical mold of the German secondary school and the democratic postulates of the U.S. secondary school, both adjusted to the popular needs and aspirations of Mexico." ${ }^{60}$ Clearly, by 1923 some key components of the new plan for secondary education responded to the uniquely Mexican postrevolutionary ethos. The four central goals of the new secundaria were to "(1) carry forth the task of correcting defects and sponsoring the general development of students begun in the primaria, (2) strengthen in each student the sense of solidarity with others, (3) create habits of unity (cohesion) and social cooperation, and (4) offer all students a great variety of activities, exercises, and teachings so that each one might discover a vocation and be able to dedicate him/ herself to cultivating it." 61 The secundaria's goals of correcting "defects" (read superstition and blind faith) while fostering solidarity and cooperation were consonant with the revolutionary ideology of rural primary schooling as well.

Unlike the primaria, however, the secundaria was still oriented toward urban, and mostly professional, classes. ${ }^{62}$ Moreover, the secundaria continued to be administered by the National University as part of its preparatory schools until a presidential decree in 1925, after which Moises Sáenz created a separate Office of Secondary Education in 1928. It was then that the secundaria became more explicitly guided by methods and principles appropriate

power should include the state's assumption of an educative role. Many argued that education should remain a family affair, with instruction the domain of the state. But by 1890 , the Mexican state had begun to provide primary schooling with important educational functions. After the Revolution, the state expanded this formative quality of public education and, modeling the German system, extended it to the secundaria. See Raúl Mejía Zúñiga, "La escuela que surge de la revolución," in Historia de la educación pública en México, ed. Fernando Solana, Raúl Cardiel R., and Raúl Bolaños M. (Mexico City: SEP, 1981), p. 223. Interestingly, in their exhortations to parents to discipline children in the home, ESF teachers in 1990 tended to maintain a distinction between educación and instrucción, emphasizing that educación begins (and for some, ends!) in the family.

${ }_{59}$ Donald J. Mabry, "Twentieth-Century Mexican Education: A Review," History of Education Quarterly 25 (1985): 222. Kamens et al. (n. 15 above), p. 118, emphasize the impact of "worldwide ideological currents," with their conceptions of progress and "social rationalization," on secondary curricula around the globe. As they put it, "few countries possess local educational traditions sufficiently entrenched to resist the highly professionalized world-level discourse concerning curricular structure and content." Yet the case here argues for a more nuanced conception of curricular integration. That Mexico adopted its model for secondary education from these "ideological currents" does not imply that important local meanings and uses failed to place their particular imprint on the course of its development.

60 Mejía Zúñiga, p. 225.

${ }^{61}$ My translation of Ernesto Meneses Morales, Tendencias educativas oficiales en México, 1911-1934 (hereafter cited as 1911-1934) (Mexico City: Centro de Estudios Educativos, 1986), p. 408.

${ }^{62}$ By 1928, there were still only seven federal secundarias in the whole country, all of them concentrated in Mexico City. In addition, there were some 32 secundarias operated by the states, and another 36 private secundarias throughout the national territory. See Meneses Morales, 1911-1934. 
to the "adolescent" life stage ${ }^{63}$ Sáenz, considered by most the founder of the secundaria, had studied at Columbia University with John Dewey and was familiar with the work of G. Stanley Hall. Yet while the U.S. high school had been developed in part to foster individual identity formation and critical thinking, the Mexican secundaria emphasized the importance of curtailing selfish individualism and creating a sense of social solidarity. Moreover, the divide between childhood (ninez) and adolescencia became enshrined in the primaria and secundaria, respectively, ${ }^{64}$ with the latter conceived as the ideal time and place for creating the revolutionary subject.

Perhaps the difference between the U.S. and Mexican approaches should be seen more as a matter of degree than of kind. To be sure, Dewey's conception of education for adolescents, rooted in the emerging Euro-American view of the misguided young in need of "emancipation," included a strong emphasis on cooperation and community. In other words, adolescents could only be emancipated from the ignorance and caprice of their condition through institutions designed to channel their energies for communal purposes. ${ }^{65}$ And just as the American high school tempered its individualism with cooperative activity, the Mexican secundaria provided individual choice amidst its core curriculum. By the end of the 1920s, the secundaria began to offer more varied options, adding to the arts and sciences a number of technical or industrial "shops" (talleres) students would choose for different possible avenues of future work or study. The goal of the secundaria was to balance the desire for a curriculum more specialized than the primaria-a curriculum that would offer students the chance to explore their vocational options - with the themes of integration and national unity. The goal, in other words, was to accommodate the "individual differences" of the students while still subordinating individual interests to the imperatives of "solidarity," "cooperation," and so-called social values. ${ }^{66}$ The "educative" function of the state was more amply reflected in this approach than in, say, the principles of critical thinking espoused by John Dewey. Indeed, Sáenz reaffirmed the state's commitment to unity and equality by suggesting the secundaria would continue to oblige Mexicans to "take the same educational path," even as it provided the opportunity for distinction and differentiation. ${ }^{67}$

${ }^{63}$ See Meneses Morales, 1911-1934, pp. 479 and 603; Santos del Real, La educación secundaria (n. 8 above), p. 3; and Nashiki A. Gómez, "Historia de la educación: La creación de la escuela secundaria," Educación 200122 (1997): 47-49. The latter quotes Sáenz as explicitly claiming that the secundaria should be "an institution destined for adolescents."

${ }^{64}$ Compare Ariés (n. 1 above), p. 177.

${ }^{65}$ Neubauer (n. 2 above), p. 182.

${ }^{66}$ Meneses Morales, 1911-1934, p. 486. In 1932, when a full Department of Secondary Education was finally created under the secretaryship of Narciso Bassols, these pedagogical goals were given an even firmer institutional grounding. See Meneses Morales, 1911-1934, p. 602.

${ }^{67}$ Meneses Morales, 1911-1934, p. 480. In one of his first documents written as a minister of education, Moisés Sáenz clearly showed his preference for the "new" secundaria over the "verbalist" and teacher-centered pedagogy of the old preparatory schools. The advantage of the new secundaria was for 
At the outset of the 1930s, the development of the secundaria took a distinct turn. Increasingly, secundarias were established to prepare workers and rural teachers. Students were drawn from the working classes, and even occasionally the peasantry, rather than exclusively from the urban-based middle and upper classes. The architect of this emerging emphasis on technical education was Education Secretary Narciso Bassols. Partly because of the onset of world recession in 1929, Bassols wished to counter the intellectual, moral, and spiritual thrust of Vasconcelos's policies with a more practical approach to national industrialization. ${ }^{68}$ Integrating the already existing normal schools, agricultural centers, and cultural missions into unitary "regional peasant schools," Bassols hoped to emphasize the teaching of better production methods for the satisfaction of local needs. Yet it was in Bassols's discourse that these methods were offered through the benevolent consideration of the state; peasants and workers were encouraged to identify themselves, first and foremost, as Mexicans, and to identify the state as the supreme representative of the nation. The state, in Bassols's view, was above the conflict of social classes, which was inherent to society. The goal of the state should be to represent the true interests of the nation. To this end, it had to achieve a certain uniformity of all Mexicans. However, this kind of national integration could be more easily achieved through straightforward steps toward economic development than through any specifically cultural action of the schools. ${ }^{69}$ This logic pervaded the movement for "socialist education," which, building on Bassols's educational philosophy, burst onto the national scene with the presidency of Lázaro Cárdenas, in 1934. One must appreciate the continuities in postrevolutionary educational thought in order to see how the apparently radical rupture of "socialist education," which privileged the interests of peasants and workers and fomented class consciousness, could be reconciled with the hegemonic intent of state action. ${ }^{70}$ The state at this time sought to leverage power against the national and international bourgeoisie by creating a powerful alliance with the working masses premised on economic development.

The presidency of Lázaro Cárdenas (1934-40) oversaw a significant growth in secondary enrollments. ${ }^{71}$ Now with an avowedly socialist educa-

Sáenz its ability to "attend to the individual differences of the students" and offer varied paths of future work or study. Moisés Sáenz, Reseña de la educación pública en México en 1927 (Mexico City: Secretaría de Educación Pública, 1928), pp. 16-19.

${ }^{68}$ Carlos Ornelas, "La educación técnica y la ideología de la Revolución Mexicana," in Graciela Lechuga, ed. (n. 53 above). p. 111.

${ }^{69}$ Ornelas, "La educación técnica," pp. 44-45, and El sistema educativo mexicano (n. 23 above),

${ }^{70}$ Córdova (n. 53 above), pp. 159-61, emphasizes that for Cárdenas socialist education meant, above all, emphasizing social responsibility over individual advancement. Cárdenas linked this social emphasis to a collective unity in nationhood.

${ }^{71}$ Sixty-one percent for the period 1934-40. Carlos Muñoz Izquierdo, "Socioeconomía de la educación privada y pública: El caso de México,” Revista latinoamericana de estudios educativos 11 (1981): 112. 
tional program, children of workers were more strongly encouraged to continue their schooling as the secundaria turned more "technical," and the curriculum included more hours devoted to practical, productive activities. Socialist pedagogical philosophy sketched the desired qualities of the new adolescent secundaria graduate: "a young person with a firm concept of responsibility to and solidarity with laboring classes and an intimate conviction of social justice, so that, upon completing his/her studies, he/she will be oriented toward community service and not the desire for private gain." 72 Thus, the secundaria was to inculcate a renewed kind of relational adolescent identity, in solidarity with class and community, while channeling the students' skills and activities into service for the greater good. It was at this time that "vocational counseling" (orientación) first appeared in the secundaria. Also at this time, the teaching of history and civics was given new emphasis. In 1932, the curriculum added a course in "civic culture" to the required courses of Spanish, foreign language (French or English), mathematics, science (biology, chemistry, and physics), geography, and history for each of the 3 years. This course added an important critical element to the curriculum, as it focused on political, economic, and legal "problems" in Mexico. By 1937, the course in civic culture had been changed to "socialist information and practice," and in 1939, official policy reaffirmed that the secundaria was "an institution fundamentally placed at the service of adolescents." 73 Students increasingly learned about class conflict and imperialism as a way of understanding Mexican history. ${ }^{74}$ They participated in student government and mutual aid societies to practice cooperative social work. Finally, students made frequent trips to shops and factories in order to gain a fuller appreciation of working-class life. ${ }^{75}$ The Cárdenas era perhaps came closest to achieving that elusive balance between "practical" activity and "critical"

\footnotetext{
${ }^{72}$ Meneses Morales, Tendencias educativas oficiales en México, 1934-1964 (n. 9 above), p. 113. This quote is based on the writings of Juan B. Salazar, Cárdenas's head of secondary education.

${ }^{73}$ Meneses Morales, 1934-1964, pp. 115-19, p. 122. The quote is from Article 60 of the regulative law of constitutional Article 3, published in the Diario Oficial, December 30, 1939.

${ }^{74}$ Vaughan, Cultural Politics in Revolution (n. 34 above); David Raby, La educación socialista en México: 1920-1940 (Mexico City: Sepsetentas, 1974). The great Argentine educator and psychologist Aníbal Ponce visited Mexico frequently during this period, and was tragically killed in an automobile crash while traveling from Morelia, Michoacán to Mexico City-see Ma. Teresa Cortés Zavala, Lázaro Cárdenas y su proyecto cultural en Michoacán (Morelia: Universidad Michoacana, 1995). Ponce had just finished a series of lectures in Michoacán, the state where I conducted my fieldwork, and some of these formed part of a book published posthumously by the Universidad Michoacana, Psicología de la adolescencia: Diario intimo de una adolescente (Morelia: Universidad Michoacana, 1938). In this fascinating piece of work, Ponce gives us a glimpse of certain concepts of adolescence that were in circulation at the time by reanalyzing the famous diary of Russian noblewoman Maria Bashkirtseff, who died young of tuberculosis after a vain and turbulent life. Taking issue with prior analyses of the diary that found in it evidence of extreme pathology, Ponce reinterprets the noblewoman's life as subject to the "individualism" and capricious femininity of her social class milieu. Situating himself amidst the socialist ethos of the day, Ponce proclaimed that adolescents would indeed fall prey to pettiness and caprice unless guided by the sentiment of the common good (p. 162).

${ }^{75}$ Meneses Morales, 1934-1964, p. 116.
} 
thinking, between technical and cultural knowledge, so coveted by Dewey and Sáenz alike.

By 1940, Cárdenas's attempt to engineer a popular social state ran into the contradictions and constraints that had always marked it. ${ }^{76}$ Even as the corporatist structure of interest representation endured, the reins of power swung over to the more conservative Avila Camacho. It did not take long for the Avila Camacho administration to begin dismantling or reversing the socialist experiments of the Cardenista period. Under Avila Camacho, the third constitutional article was once again amended, this time deleting all references to socialism and declaring primary schooling compulsory. Conservative Catholic interests, such as the Unión de Padres de Familia, were given greater voice, and in states like Michoacán — where my field site ESF is located-private church schools expanded rapidly. If the school under Cárdenas had given preference to workers and become the school of struggle, under Avila Camacho's first education secretary, Véjar Vázquez, it would become the "school of love," and under his second secretary, Torres Bodet, the school of unity. Children of all classes would receive equal treatment and equal access to the Liberal promise of progress, democracy, and social justice. Official educational discourse thus reinstated the primary importance of "national unity" and reconciliation above class struggle, and secondary education, especially, emphasized the preparation for productive work and a harmonious civic life. ${ }^{77}$

In reality, the predominant emphasis on national unity and progress through individual development that emerged under Avila Camacho encouraged educational practice to fruitfully incorporate themes from the previous postrevolutionary periods. Themes of national integration and moral redemption from the immediate pre- and postrevolutionary epochs (J. Sierra, J. Vasconcelos) merged with Bassols's valorization of practical skills for a more productive life. However, educational discourse and practice also began to return even more to its Liberal roots, emphasizing equality of opportunity and social mobility. As Soledad Loaeza points out, this emphasis allowed the state to legitimize itself both by providing increased channels for social mobility (whether real or merely perceived) and by propagating nationalist values identified with the state. ${ }^{78}$

\footnotetext{
${ }^{76}$ Córdova; Nora Hamilton, The Limits of State Autonomy: Post-revolutionary Mexico (Princeton, N.J.: Princeton University Press, 1982)

${ }_{77}$ Verónica Oikión Solano, Michoacán en la vía de la unidad nacional, 1940-1944 (Mexico City: Instituto Nacional de Estudios Históricos de la Revolución Mexicana/Secretaría de Gobernación, 1995), pp. 290-306. In 1946, Education Secretary Torres Bodet was also influenced by the internationalist themes of the newly created United Nations, with its call for an education in global solidarity. See Esteban Moctezuma Barragán, La educación pública frente a las nuevas realidades (Mexico City: Fondo de Cultura Económica, 1993), p. 52.

${ }^{78}$ Soledad Loaeza, "La educación nacional entre 1940 y 1970," in Lechuga, ed. (n. 53 above), pp. 104-5. Ornelas, El sistema educativo mexicano, also shows how the "political philosophy" of the Mexican educational system, always rooted in liberal discourses of individual rights, anticlericalism, and rational progress, endured even throughout the socialist interregnum of 1934-46.
} 
To be sure, the secundaria expanded under Avila Camacho at an even greater rate than under Cárdenas. Once again, the uniquely "adolescent" character of the institution was proclaimed, and reformers sought to protect the secundaria from the "threat of two contradictory invasions": the primaria and higher education. ${ }^{79}$ The secundaria was to have its own personality, its own agenda. Despite the fact that Cárdenas had sought to conceptualize the secundaria as an agent of social transformation and enfranchisement, and despite the claims that the secundaria began to grow after 1940 as a response mainly to urban middle-class aspirations,${ }^{80}$ in fact the secundaria continued to provide an important means of social mobility for members of working and peasant classes. What changed mostly was the rhetoric that framed such mobility. Before 1940, workers and peasants were encouraged to use the school as a tool for class empowerment and enfranchisement. After Cárdenas, however, the state entered into a period of more comfortable alliance with national and transnational capital. In the official discourse of this period, the interests of the nation, of subordinated classes, and of capital were considered convergent; each could win in the hegemonic formula for national development and the stabilization of a "revolutionary" regime.

This formula has provided the basic continuity in policy and practice around the secundaria at least until 1980, perhaps even until $1993 .{ }^{81}$ In the period from 1950 to 1970 , there was a 1,000 percent increase in secundaria enrollments, ${ }^{82}$ and growth, although reversing slightly in the late $1980 \mathrm{~s}$, has steadily continued since then ${ }^{83}$ Even current official discourse recognizes that until the mid-1970s, the state was primarily concerned with covering educational demand through quantitative expansion. ${ }^{84}$ Under some version

${ }^{79}$ Meneses Morales, 1934-1964, p. 283.

${ }^{80}$ Muñoz Izquierdo, p. 112.

${ }^{81}$ Although many point to the "populist" reforms and rhetoric of the Echeverría administration $(1970-76)$ as a significant departure from this pattern, I prefer to see them as an intensification of previous developments. The attempt to rearticulate state hegemony after the political rupture of 1968 involved the reactivation of populist rhetoric from the Cárdenas period but did not fundamentally alter educational structures. If important changes were made at the level of preparatory and university education, similar changes were not as salient in basic education. Fuentes notes the emphasis given to "technical" education during this time, but he also suggests that this policy was really just a continuation of trends initiated in the two previous administrations, and traceable ultimately to Narciso Bassols and the vocational themes of Cardenista educational thought. See Olac Molinar Fuentes, "Enseñanza media básica en México, 1970-1976," Cuadernos políticos 15 (1978): 90-104.

${ }^{82}$ David Barkin, "Education and Class Structure: The Dynamics of Social Control in Mexico," Politics and Society 5 (1975): 186. Much of this increase was due to the growing participation of female students, who came to form half the student body in most secundarias by the late $1970 \mathrm{~s}$.

${ }^{83}$ Fuentes, "La educación secundaria" (n. 11 above), p. 61.

${ }^{84}$ The federal educational reform of 1973, under Echeverría, provided the conceptual basis for a thorough overhaul of schooling, although many of its details were never fully implemented. This law, moreover, reiterated that state education had four "functions" in society: academic, socialization, economic, and distributive. It was this law that spawned the "Chetumal Reforms" of 1974, a reorganization of the secundaria curriculum. After 1974, most secundarias began to teach integrated subject areas, called "áreas" (natural sciences, social sciences, Spanish, etc.), rather than the older system of individual subjects, called "asignaturas." See M. Gallo, "Las políticas educativas en México como indicadores de una situación nacional, 1958-1976," in Cuadernos de la Casa Chata, no. 155 (Mexico City: CIESAS-INAH, 1987), p. 56. 
of the rallying cry, "Educación para Todos," the state further sought to fulfill popular claims for equality, participation, and social justice through schooling. ${ }^{85}$ And several times again, in the 1950s and the 1960s, official policy restated the primordial goal of the secundaria: an education designed for the "integral formation" of adolescents. ${ }^{86}$

In the early 1960s, the first federal secundarias técnicas were built. When a new secundaria was built in a large rural community or small provincial city, it was likely to be a técnica rather than a "general" secundaria. The vocational specialties of the new técnicas were often tailored to the unique needs and demands of the local economy: carpentry, clerical work, auto mechanics, even fishing or forestry. The técnica was said to offer its graduates these more appropriate skills for immediately entering regional labor forces, or for continuing on to more advanced vocational studies. General secundarias, however, tended to be built only in the larger cities. ${ }^{87}$ In this fashion, the state could fulfill its obligation to the popular demand for schooling while attempting to redirect students from the more desirable course of liberal university studies toward the vocations ${ }^{88}$ Not only did this strategy promise to match more students with potential jobs, it also assuaged those in the national bourgeoisie who were desperate for more qualified technical labor. ${ }^{89}$ Ironically, the strategy was less successful than had been hoped. The status value of university professional studies, along with their promise of greater earning power, still discouraged many students from pursuing the route of technical studies.

With the onset of economic crisis in 1982, and the shift to a neoliberal economic model of privatization and free trade, secondary enrollments began to level off. By 1990, my research indicated a curious dilemma in many families' educational expectations and practices. The secundaria, seen by many as an intermediate stage on the path to the university, had finally come to form a vital part of most families' livelihood strategies. Indeed, the expectation of at least some secundaria attendance had become woven into the

\footnotetext{
${ }^{85}$ Not until the late 1970 s did education officials turn their attention seriously to the problem of "quality" in basic education; the premise of such a shift was that quality had always been secondary to the goal of providing the bare minimum of schooling to as many people as possible.

${ }^{86}$ Meneses Morales, $1934-1964$ (n. 9 above), p. 411, 482.

${ }^{87}$ Reyes Rocha (n. 25 above), p. 57.

${ }^{88}$ Like many other commentators, Fuentes, "Enseñanza media básica," notes that from 1970-76, during the regime of Luís Echeverría, the state, in addition to seeking expansion of enrollments and the modernization of the curriculum, wished to give secondary schooling a firm vocational grounding in order to divert more students away from professional studies at higher educational levels.

${ }^{89}$ In the late 1970 s, the state also pursued this strategy at the level of "educación media superior," which follows the secundaria. A system of terminal vocational high schools, called CONALEP (Colegio Nacional de Educación Profesional Técnica), was instituted throughout the country. Similarly, vocational and liberal curricula were integrated in the CBTIS or CBTA (Central Bachillerato Tecnológico Industrial y de Servicios, or Agropecuaria), a nationwide system of high schools that gave students the option of taking a terminal vocational degree or continuing on to higher education. By 1997, however, CONALEP had just begun to offer a college preparatory component, and the system of CBTIS and CBTAs had modified their curricula further in the direction of university preparation.
} 
local cultural fabric of all but the poorest or smallest communities and social classes. ${ }^{90}$ Studying in the secundaria was clearly a kind of adolescent rite of passage; my data indicate that families with children in secundaria were far more likely to refer to them as adolescentes, with the accompanying social and emotional problems, than were families with youth out of school, who used terms like joven or muchacho. Yet by 1990 the possibility of full professional employment had also become increasingly unattainable for the majority of university graduates. It was commonly believed that an entrepeneurial taco vendor with little education could make more money than an engineer or doctor with a university degree. The latter, after all, had few opportunities to exercise their careers. The symbolic significance of secondary schooling, and the merit of having "culture" (cultura), thus entered into contradiction with economic realities, and this contradiction appears to have generated a great deal of ambivalence about continued secondary attendance.$^{91}$ It was in this atmosphere of popular ambivalence that the curricular reforms and constitutional amendment of 1993 were announced. In principle, secundaria attendance was now a citizen's obligation to the state.

What was the political-economic context of these new educational reforms? One cannot understand them without reference to the growing impact of economic globalization and neoliberal discourses of "modernization." By 1992, the presidential regime of Carlos Salinas de Gortari had resolutely aligned itself with international trends in educational modernization. That same year, the first National Pact on the Modernization of Basic Education (ANMEB) was promulgated by the Secretariat of Public Education. The Pact reached between federal and state governments and the official national teachers' union (SNTE) outlined several major innovations, including the reformulation and privatization of basic textbook production, a thorough decentralization of educational administration, a merit structure for teachers' career advancement, and the now obligatory secondary school cycle. The predominant justification for these reforms was couched in the new language of modernization: a rationalized and more efficient, "quality" education for greater "productivity" in a global economy. By the middle of 1993, the initial Pact became converted into law with the amendment of Constitutional Articles 3 and 31, making secondary attendance both a citizen's right (Article 3) and obligation (Article 31). Most of the Pact's reforms were also written into law with the passage of a new Ley General de Educación (General Educational Law) that same year, replacing the existing law from $1973 .{ }^{92}$

\footnotetext{
${ }^{90}$ Levinson, "Social Difference and Schooled Identity" (n. 19 above); Compare Christopher J. Martin, " 'Let the Young Birds Fly': Schooling, Work, and Emancipation in Rural West Mexico," Compare 24, no. 3 (1994): 64 .

${ }^{91}$ Levinson, "Social Difference and Schooled Identity."

${ }^{92}$ I am indebted to observations by Beatriz Calvo Pontón (personal communication) (n. 39 above) for some of the points in the forgoing paragraph, especially the centrality of the notion of "quality"
} 
On balance, the new educational laws may augur a certain irony in the fate of Mexican adolescence: the sense of uniqueness and special considerations for adolescence adapted from older globalizing discourses and enacted historically in the secundaria now threaten to be displaced by the more recent globalizing discourses of modernization and productivity. The safe space of the secundaria for adolescent development may be overwhelmed by the capitalist imperative of productivity. Will the new law affect local perceptions of educational opportunity and life course development, further cloistering the young, potentially rebellious unemployed? Does the new curriculum still address Mexican concerns about adolescence and the balance between individualism and collectivism? We can begin to answer these questions by examining the curricular changes imposed by the Program for Educational Modernization (PME) and put into effect with the new laws in 1993.

\section{Curricular Reform in 1993: A Brief Thematic Analysis}

By 1994, all secundarias throughout the Mexican Republic were to have implemented the new national curriculum drafted as part of the Program for Educational Modernization. This curriculum, along with an official statement of justification and support, was published in book form in 1993 and widely distributed by the Secretariat of Public Education. While it is always a difficult matter to read into official documents the complex forces constituting an educational reform, this document contains the most visible and well articulated statement about the new program for secondary education. The analysis that follows constitutes an exposition and critical interrogation of this document.

The new plan for secondary education appears to reflect the "contradiction" between forming active democratic citizens and training workers that Ornelas and others have noted. On the one hand, the document grounds the rationale for educational reform in the "deep process of change and modernization" that continues to affect the country. This modernization appears to mean, above all, that "economic activities and work processes are evolving toward higher levels of productivity and more flexible forms of organization which are indispensable in an integrated and highly competitive world economy." And the document also exhorts the population to uphold its own commitment to higher educational achievement for the good of the nation. Only with a more extended period of basic education will the new generations be able to "incorporate themselves responsibly into adult life and productive work." Each time the general goals of the secundaria are

(calidad) in educational provision, and its essential link to the imperative of economic "productivity." See also Beatriz Calvo Pontón, El acuerdo nacional para la modernización de la educación básica: Una interpretación regional desde la frontera Norte, Cuadernos de Trabajo no. 11 (Ciudad Juárez, Chihuahua: Universidad Autónoma de Ciudad Juárez, Unidad de Estudios Regionales, 1993). 
mentioned, the goal of "flexible and productive incorporation into the world of work" appears to have pride of place ${ }^{93}$ Through a familiar globalizing rhetoric, the new plan of studies thus invokes the challenge of economic competition and technological change, while making the traditional state plea for "responsible" national citizenship.

Yet the plan is also a remarkably progressive document, establishing the responsibility of the federal government to "undertake an important effort in order to make secondary education accessible to all." ${ }^{94}$ It mentions equal distribution of wealth, advanced democracy, tolerance and security in social life, and a responsible relationship to the environment among its eventual pedagogical goals. And it establishes that a principal aim of the secundaria should be to stimulate "an active and reflexive participation in the social organizations and in the political and cultural life of the nation." ${ }^{55}$ What is notable about these statements is the addition of phrases about "advanced" democracy, tolerance, and the environment. Such concerns arise from growing political opposition and ecological deterioration in the Mexico of the 1980s, with their accompanying backlash of state repression. References to social justice, equality, and active citizenship, however, reflect perennial themes in Mexican educational discourse. More skeptical observers, drawing on the unfortunate evidence of history, tend to highlight the demagoguery of such discourse. ${ }^{96}$

After confirming the "basic character" of the knowledge imparted in both primaria and secundaria (foreign and national language, math, sciences, geography, and history), the new plan goes on to assert the need for a more coherent articulation between primary and secondary levels-a perennial concern since the secundaria's founding. This need justifies the most salient topical aspect of the new plan: the return to teaching by individual "subject" (asignatura) rather than "área." The earlier reforms of 1974 had encouraged secundarias to adopt a more integrated subject curriculum, in which biology, chemistry, and physics would be taught conjointly in 7 weekly hours of "natural sciences," and history, geography, and social studies would be taught conjointly in 7 weekly hours of "social sciences." Most secundarias outside Mexico City and some of the other major urban centers appear to have adopted this curriculum of "áreas," while Mexico City schools largely continued to teach the older asignaturas. The new plan suggests that teaching by "áreas"

${ }^{93}$ SEP, Educación básica secundaria (n. 10 above), pp. 9-12. Above quotes, respectively, from p. 9, p. 9 , p. 10, and p. 12.

${ }_{95}$ Ibid., p. 9; see also pp. 12-13.

95 Ibid., pp. 9-12.

${ }^{96}$ See, e.g., Pablo Latapí Sarre, “Gobernación manipuladora,” Proceso 1115 (March 15, 1998): 4042. Writing about the ANMEB, Beatriz Calvo Pontón, "El acuerdo nacional," p. 12, argues that the prominence of terms like "justice," "democracy," "liberty," "equality," and the like, while necessarily part of the modernization rhetoric, remain strangely abstract and "disarticulated" from concrete realities in comparison to terms like "market" and "production." 
failed to contribute to a solid and well-ordered "disciplinary formation" of students, ${ }^{97}$ and mandates a return to asignaturas. Biology, chemistry, and physics receive a roughly equal treatment across the 3 years of secondary studies, while the former social science "area" has been disaggregated into courses of history (world and Mexican) across all 3 years, and courses of geography (world and Mexican) and civics across the first 2 years.

Among the notable changes to the curriculum are the formal introduction of two new courses during the third and final year of studies: a course in "educational orientation," meant as an extended form of vocational counseling, and a final elective course to be determined by each school according to its own needs, specialties, and interests. In contrast to the detailed and elaborate curricular guidelines provided for all other "academic subjects," what really stands out about these two newly proposed courses is the absence of any concrete guidelines in the published study plan. One is left to wonder about how these courses will in fact be developed at local schools. When I returned to ESF for a brief visit in 1995, the course on "educational orientation" appeared to be cobbled together in ad hoc fashion from the same kinds of surveys and skills inventories that had been applied occasionally by the school's vocational counselor in 1991; occasional lessons on health and sexuality had also been incorporated. Thus, a course designed to achieve a more rational integration of the labor force and the market is foundering for lack of resources and preparation. The elective courses, however, appeared to be quite popular with students. In 1997, students could choose between courses in ecology, photography, state and local history, and the local indigenous language.

Finally, alongside the academic subjects, the new study program continues to allot the same number of hours to so-called development activities. This is one aspect of the curriculum that remained virtually unchanged. Across all three years, students are to take 2 weekly hours of "artistic expression and appreciation," 2 weekly hours of physical education, and 3 weekly hours of "technological education." As the new program explains, "The definition of these as activities and not as academic subjects is not meant to imply that they play a lesser role in the student's formation; rather, it is meant to highlight the importance of carrying them out with greater flexibility, without being subject to a rigid and uniform program, and with a higher possibility of adaptation to the needs, resources, and interests of the regions, schools, teachers, and students." ${ }^{98}$ The inclusion of art, sport, and technology across all 3 years of secundaria signals an ongoing commitment to the aesthetic and practical activities that have always formed an important part of the postrevolutionary educational ethos.

${ }^{97}$ Ibid., p. 11.

${ }^{98}$ Ibid., p. 14. 
Reading through the introductory section of the program, I was struck by the absence of any reference to the needs or interests of Mexican "adolescents." Where was the historical link to this globalizing conception of the transition to adulthood? Had the concept of adolescence been effectively erased from official discourse about secondary education? It is fascinating to note that an earlier draft document of the Modernización Educativa (Plan for Educational Modernization), the projected plan of studies for basic primary and secondary education circulated in 1990, gave much more importance to adolescence. This plan said the secundaria should emphasize the "development of critical and creative thought" for the adolescent's "responsible participation in society." In fact, the very first purpose of the secundaria mentioned is the "knowledge of the characteristics and problems of adolescence for self-acceptance and deeper self-knowledge." ${ }^{99}$ Moreover, this earlier proposal for curricular reform included courses in "health and hygiene," "adolescence and sexuality," and "civic responsibility" (moral ciudadana) across the 3 years of secundaria, respectively. ${ }^{100}$ Here, then, was a remarkably open and reflexive educational approach to the experience of being an "adolescent"- an approach which would vanish, after more internal debate and negotiation, in the final plan. ${ }^{101} \mathrm{Had}$ the productivity imperative finally displaced any reference to the needs of adolescence?

In reviewing the major part of the 1993 document, the proposed contents of the academic subjects, I took special interest in the "civics" (civismo) course. It was here, I thought, that I might find some reference to the process of identity formation in adolescence. Certainly I would find an affirmation of the priority of the nation as a frame of reference for students' effort and conduct. This was where I believed I would observe the triumph of revolutionary nationalism over the narrower prescriptions of liberal individualism.

There is no reference to adolescence in the civics course, but there is indeed a rich reflection of the importance of solidarity in national life. The goal of civics is articulated in terms of "supporting the continuity of [the student's] formation and his/her insertion into the activities of the collectivity and productive life." ${ }^{102}$ This collective socialization should not proceed through merely "declarative" statements; rather, the transmission of such

\footnotetext{
${ }^{99}$ SEP, Modernización educativa, 1989-1994: Los planes de estudio de la educación básica (Mexico City: SEP, June 1990), p. 46.

${ }^{100}$ Ibid., p. 49.

101 The process by which the final plan emerged was rather less than transparent, although many observers have emphasized the increased role played by the Church and the conservative National Parents' Union, especially since the 1993 relaxation of previously severe constitutional limits on church activity in public life. Because sex education was clearly an important part of studying "adolescence" in school, the Church and its allies launched an attack on the early version of the plan. See Marta Lamas, "Scenes from a Mexican Battlefield," NACLA Report on the Americas 31, no. 4 (January/February 1998): $17-21$.

${ }^{102}$ SEP, Educación básica secundaria, p. 121.
} 
values will only become effective if they "correspond to the kinds of relationships and practices which characterize the activity of the school and the school group." ${ }^{103}$ Thus, the section on civics appears to endorse the most progressive values and styles of pedagogical engagement. In addition to a continued emphasis on patriotism and the strengthening of national identity, there is a large place given to themes of human rights and substantive democracy. Teachers are encouraged to undertake an analysis of such themes, as well as concepts of "human dignity, liberty, justice, equality, solidarity, tolerance, and truth," which are said to be central to the formation of national values. And such concepts should not remain on an abstract plane. Teachers should find ways to link "real referents" to such concepts, bringing up everyday problems and issues and fomenting analysis through "participatory methods such as roundtables and debates." 104

\section{Discussion and Conclusions}

The secundaria's new program of students still highlights the "integral formation" of the student for civic life, but drops all reference to adolescence. Should we make much of this textual oversight? Will teachers and administrators still serve "adolescence," and will the new generation of secundaria students still learn to understand themselves as "adolescents" attending a school designed for this "difficult stage" of their lives? Will the better part of students' formation take place around themes of democracy, social justice, and national unity or, as critics of the neoliberal regime suggest, the theme of individual advancement within a competitive framework of rationalized economic development? Are these themes, after all, mutually incompatible?

Given the initiatives highlighted in the latest plan for secondary studies, on balance it would seem there has been a subtle shift toward a more liberal modernist emphasis on an adolescent's development toward autonomy, individual rights, and freedom of choice in pursuing career options. This shift accompanies a notable commitment to open discussion of issues about human rights and democracy and a renewed attention to the solid formation of technically skilled workers. In effect, there appears to have been an erosion of the ethos of revolutionary nationalism, with its collectivist prescrip-

${ }^{103}$ Ibid., p. 122; Most secundarias form students into cohorts, called grupos escolares, which attend virtually every class and activity together, and which remain an organizational unit for all 3 years of the students' tenure in the school. This statement is especially significant in light of my discovery of the importance of the "grupo escolar" as an intense focus of socialization at ESF. In fact, I argue that teachers at ESF discursively construct the grupo escolar as a microcosm of the nation, where students must learn to overcome their differences and work together for the collective good. See Bradley A. Levinson, "Todos somos iguales: Cultural Production and Social Difference at a Mexican Secondary School" (Ph.D. diss., Department of Anthropology, University of North Carolina, 1993), chap. 5, and "Student Culture and the Contradictions of Equality at a Mexican Secondary School," Anthropology and Education Quarterly 29, no. 3 (1998): 1-30.

${ }^{104}$ SEP, Educación básica secundaria (n. 10 above), pp. 122-23. 
tions for adolescent formation. Although this ethos is still clearly observable, especially in the program for civic studies, it now takes a backseat to the imperative of individual development. The introduction of "elective" and "orientation" courses suggests a further emphasis on individual options. Interestingly, the prominence of themes of democracy and human rights implies a tacit admission that such principles have not always been adequately respected in Mexico, perhaps even less so in recent years. There is an assumption, too, that the prior emphasis on collective life perhaps allowed violations of democracy and individual human rights to be rationalized in terms of the need for a strong state working for the supposed common good.

A purely textual analysis of the latest curriculum, of course, only points us further in the direction of history and social practice to sketch out the immediate future of the secundaria and its associated category, adolescencia. In this article, I have shown how policy and curriculum for the Mexican secundaria incorporated themes from the cultural underpinnings of Mexican institutions, including hierarchical holism, liberal individualism, and collective revolutionary nationalism. The secundaria was adapted from a Liberal Euro-American model of adolescent education, but its practical course of development, subject to the ideological swings of postrevolutionary regimes, incorporated numerous influences. Designed early on to accomplish the "integral" formation of the adolescent for community and national life, the secundaria took on the values of social justice, respect for work, national unity, and economic development impressed upon it by successive administrations. By the 1980s, however, the secundaria had become an important stepping-stone on the path to professional studies for more than half of all Mexican students; in practice the school had come to deemphasize the "formative" and "practical" elements necessary for students' immediate incorporation into adult social life, favoring instead the "preparatory" (propedeútica) role for future studies. As Rafael Quiroz has argued, the increased fragmentation of the new secundaria curriculum, undoubtedly linked to this preparatory emphasis, may create even more obstacles for the useful construction of everyday knowledge. ${ }^{105}$ Moreover, the secundaria's preparatory role has clearly failed to meet the challenges of economic crisis, which began in the early 1980s. The 1993 program for educational modernization and its accompanying compulsory law for secundaria attendance were implemented at a time when the knowledge and credentials of advanced study had become either undesirable or unattainable for a growing number of Mexicans.

${ }^{105}$ Rafael Quiroz, "La reforma curricular de la escuela secundaria en México," in Educación, ciencia y tecnología: Los nuevos desafios para América latina, ed. J. L. Labastida, G. Valenti, and L. Villa (Mexico City: Universidad Nacional Autónoma de México, 1993), pp. 143-48, and Los cambios de 1993 en los planes y programas de estudio en la educación secundaria (Mexico City: Departamento de Investigaciones Educativas, 1995). 
What might be the consequence of such developments for the varying local conceptions of adolescence in play at a school like ESF? Since the establishment of ESF in 1943, the sociocultural category of adolescencia has continually expanded to encompass the legions of school-bound youth. The growth of secondary schooling and the increased consumption of cultural media designed for youth has extended the moratorium of childhood well into adolescence and provided a social space for the creation of intensive peer cultures. ${ }^{106}$ If the primordial goal of the Mexican secundaria, very much in evidence at ESF in 1991, has been the integral formation of student values for social life, many school actors emphasize that this formation must take place during a highly volatile and emotionally charged adolescent stage, when student problems and conflicts come to the fore. ${ }^{107}$ Yet beyond the new course on "educational orientation," which actually highlights the schoolto-work transition or the choice of specialized studies, there is little to suggest that such conflicts will be given adequate attention. However, the enduring view of the secundaria as a carefree training ground for camaraderie and social affiliation has been minimally accommodated in the new curriculum by the continued emphasis on collective socialization. The "participatory methods" recommended by the plan might successfully channel students' spontaneous enthusiasm toward productive pursuits.

This emphasis on collective socialization is crucial and points toward that enduring dimension of Mexican educational ideology and culture most likely to place its imprint on global curricular trends. After all, Mexicans across social classes tend to conceive of adulthood more in terms of achieving a sense of social responsibility, of enduring commitment to a functioning primary social unit. That is why the relational sense of identity and group solidarity encouraged in the secundaria appears to find strong support in prior modes of family and community socialization. ${ }^{108}$ Despite the incursions of liberal philosophy, U.S. cultural media, and neoliberal economics, indeed despite the new curriculum's emphasis on personal choice, one sees little of the intense North American cultural drive for individuation during the period of adolescence. Rather, Mexicans often describe adolescence as a time when youth may suddenly go astray, when their noncooperative impulses may get the best of them, and the predominant emphasis is on further social integration, learning how to "pull" (jalar) with the family or school or work group. Mexican households across social classes, moreover, also tend

\footnotetext{
${ }^{106}$ See Bradley A. Levinson, We Are All Equal (n. 19 above), and "Who Needs School? Electronic Media, Cultural Commodities and the Formation of Youth in (Post) Modernizing Mexico" (paper delivered at the annual meeting of the American Anthropological Association, November 21, 1993, Washington, D.C.)

${ }_{107}$ See José Valencia, “¿Quiénes son los estudiantes de secundaria?” in IEEPO, ed. (n. 8 above), pp. 223-47.

${ }^{108}$ Compare White (n. 3 above), who writes about the relation between Japanese schooling and conceptions of adolescence.
} 
to function as collective social units. ${ }^{109}$ Even before the current period of economic crisis, children most frequently envisioned the transition into adulthood, and the pursuit of formal studies, largely in terms of contributing to the household and pleasing the parents (usually the mother). The goal of personal expression or fulfillment is almost always subordinated to the "moral economy" and affective relations of the household. ${ }^{110}$

Finally, there is the question of the secundaria's viability as an institution serving "adolescent" needs. As the economic crisis has intensified in recent years, many urban households have shored up their resources and sought more immediate opportunities for income and employment. The leveling off of secondary enrollments suggests that families are having a harder time sustaining their older children in school. Perhaps it also suggests a devaluation of the secundaria, despite what I have already noted about the secundaria's regularization as a route to social success. It is ironic that the Mexican state should choose this time to attempt an expansion of the secundaria and a constitutional mandate to make secondary schooling compulsory. While it is true that most employers in urban labor markets now require their workers to have a secondary graduation certificate, ${ }^{111}$ it is also true that the informal economy continues to offer a more viable and immediate source of income to many Mexican youths. Unless the state can generate more investment income and commit enough resources to make the secundaria a realistic option for families and their children, and unless the state can find the means to raise teacher salaries, the secondary system will continue to experience a crisis of enrollment and morale. As some families encourage their children to pursue technical employment or professional studies, many others will only be able to look on with envy or indifference. Prevailing concepts of adolescence as a problematic and prolonged, but relatively safe period of socialization - an institutionalized transition to adulthood-may well come

\footnotetext{
${ }^{109}$ Henry A. Selby, Arthur D. Murphy, and Stephen A. Lorenzen, The Mexican Urban Household: Organizing for Self-Defense (Austin: University of Texas Press, 1990); Larissa Adler Lomnitz and Marisol PérezLizaur, A Mexican Elite Family, 1820-1980: Kinship, Class, and Culture (Princeton, N.J.: Princeton University Press, 1987); Christopher J. Martin, "Let the Young Birds Fly" (n. 90 above), and "To Hold One's Own in the World: Issues in the Educational Culture of Working Class Families in West Mexico," Compare 20 (1990): 115-39, and "Economic Strategies and Moral Principles in the Survival of Poor Households in Mexico: An Urban and Rural Comparison," Bulletin of Latin American Research 15, no. 2 (1996): 193-210. One must still be careful, when characterizing households as solidary units of production and consumption, not to overlook the perennial conflicts of interest constituted by gender and age. See Lourdes Benería and Martha Roldán, The Crossroads of Class and Gender: Industrial Homework, Subcontracting, and Household Dynamics in Mexico City (Chicago: University of Chicago Press, 1987).

${ }^{110}$ Martin, "Let the Young Birds Fly."

${ }^{111}$ Beatriz Calvo Pontón, Educación pública y modernización educativa: Un reto a la democracia en México, Cuadernos de Trabajo no. 30 (Ciudad Juárez, Chihuahua: Universidad Autónoma de Ciudad Juárez, 1996). See the revised and translated work Beatriz Calvo Pónton, "The Policy of Modernization of Education: A Challenge to Democracy in Mexico," in Ethnic Identity and Power: Cultural Contexts of Political Action in School and Society, ed. Yali Zou and Enrique T. Trueba (Albany: State University of New York Press, 1998), pp. 159-85.
} 
under siege. And just as the secundaria now fosters the development of most adolescents into productive and socially committed youths and adults, its future role may be to even more emphatically sort the privileged professionals from those who come to a desperate adulthood through the home, the workplace, or the streets. 